\title{
Metabolism of oestradiol-17 $\beta$ and progesterone in the white rhinoceros (Ceratotherium simum simum)
}

\author{
J. E. Hindle and J. K. Hodges* \\ Institute of Zoology, Zoological Society of London, Regent's Park, London NWI $4 R Y, U K$
}

\begin{abstract}
Summary. ${ }^{14} \mathrm{C}$-Labelled oestradiol- $17 \beta$ and progesterone $(50 \mu \mathrm{Ci}$ each $)$ were injected i.v. into an adult female white rhinoceros and all urine and faeces collected separately over the next 4 days. The total recovery of injected label was $61 \%, 25 \%$ being present in the urine and $36 \%$ in the faeces. Of the radioactivity recovered, $69 \%$ was excreted on Day 2 of the collection period. Repeated extraction of samples obtained on Day 2 showed that, of the radioactivity in faeces, $92.4 \%$ was associated with unconjugated steroids whereas in the urine the proportion of conjugated and unconjugated steroids were similar $(41.2 \%$ and $51.4 \%$ respectively). After phenolic separation of urinary steroids, HPLC followed by derivatization and recrystallization techniques identified progesterone as the major component of the unconjugated portion with 4-pregnen$20 \alpha$-ol-3-one as the principal metabolite in the conjugated fraction. Pregnanediol was not present. Oestrone appeared to be the most abundant oestrogen metabolite with smaller but significant amounts of oestradiol-17 $\beta$ and oestradiol-17 $\alpha$ in the unconjugated and conjugated fractions respectively. Small amounts of progesterone were found in the faecal extract in which the radioactivity consisted mainly of oestradiol- $17 \alpha$ and oestradiol-17 $\beta$. The results have established the major excreted metabolites of oestradiol $-17 \beta$ and progesterone in the white rhinoceros and the development of more appropriate assay methods for monitoring ovarian function in African rhinoceroses should now be possible.
\end{abstract}

Keywords: metabolism; oestradiol-17ß; progesterone; urine; faeces; rhinoceros

\section{Introduction}

Urinary hormone analysis has been increasingly applied as a non-invasive method for assessing reproductive function in mammals (Lasley, 1985; Hodges, 1986; Hodges \& Green, 1989). Assays for urinary oestrone conjugates and pregnanediol-3-glucuronide have been used to monitor ovarian activity in a number of ungulates, including the Indian rhinoceros (Kassam \& Lasley, 1981; Kasman et al., 1986). However, concentrations of urinary pregnanediol glucuronide and oestrone conjugates are low or non-detectable and show no cyclical changes corresponding to ovarian follicular or luteal activity in either the black (Ramsay et al., 1987) or white (Hodges \& Hindle, 1988) African rhinoceroses.

Species differences in steroid hormone metabolism and excretion provide a possible explanation for this difference but no detailed information on metabolism of ovarian steroids is available for the African rhinoceros. The present study was therefore designed to investigate the metabolism and route of excretion of ovarian steroids in a female southern white rhinoceros by identifying the major excretory products of intravenously injected radiolabelled oestradiol-17 $\beta$ and progesterone in both urine and faeces.

*Present address: Deutsches Primatenzentrum GmbH, Kellnerweg 4, D-3400, Gottingen, West Germany. 


\section{Materials and Methods}

\section{Animal and housing}

The experimental animal was an adult female southern white rhinoceros (Ceratotherium simum simum), estimated age 31 years, housed indoors at Whipsnade Wild Animal Park, Zoological Society of London. Although it is not clear whether a white rhinoceros of this age would have functional ovaries, this animal was thought to be in reproductive quiescence since parturition 8 months previously.

\section{Preparation and injection of radiolabel}

The radiochemical purity of $\left[4-{ }^{14} \mathrm{C}\right]$ oestradiol- $17 \beta$ (sp. act. $56 \mathrm{mCi} / \mathrm{mmol}$ ) and $\left[4-{ }^{14} \mathrm{C}\right]$ progesterone (sp. act. $56 \mathrm{mCi} / \mathrm{mmol}$ ) (Amersham International, UK) was established by thin-layer chromatography. Each label $(50 \mu \mathrm{Ci})$ was evaporated under nitrogen and the residues redissolved separately in ethanol, then combined. A total volume of $1 \mathrm{ml}$ including a rinse and containing $220 \times 10^{6}$ d.p.m. was removed and added to a further $1 \mathrm{ml}$ ethanol containing $1 \mathrm{mg}$ oestradiol-17ß and $10 \mathrm{mg}$ progesterone (Sigma, Poole, Dorset, UK) as carriers. After adding $8 \mathrm{ml} 30 \%(\mathrm{w} / \mathrm{v}$ ) propylene glycol in water, the solution was filtered through a $0.22 \mu \mathrm{m}$ (Millipore) filter unit before injection. On the morning of Day 1, the animal was anaesthetized with $1.25 \mathrm{ml}$ etorphine hydrochloride (Immobilon: C-vet, Bury St Edmunds, Suffolk, UK), and the radiolabel injected into an ear vein. After $10 \mathrm{~min}$ the animal was revived with $2 \mathrm{ml}$ diprenorphine hydrochloride (Revivon; C-vet).

\section{Collection and storage of samples}

All urine and faeces were collected separately each day for 4 days (Days 1-4) following the injection of radiolabel on Day 1. To prevent contamination with urine, faeces were removed within $2 \mathrm{~min}$ of voiding. The total weight of faeces excreted during each day was determined and $1 \mathrm{~kg}$ portions were stored at $-20^{\circ} \mathrm{C}$. Urine was collected in a receptacle beneath the external outlet of the enclosure drain. The urine was mixed, the volume recorded and 1 litre portions were stored at $-20^{\circ} \mathrm{C}$, with sodium azide (final concentration $0 \cdot 1 \%, w / v$ ) as preservative.

\section{Analysis of excreted material}

The protocol for the analysis of urine and faeces is shown in Fig. 1.

\section{Distribution of radioactivity}

Urine. Radioactivity in $1,0.5$ and $0.25 \mathrm{ml}$ volumes of urine was counted, in triplicate, with $10 \mathrm{ml}$ scintillation fluid (Scintran; BDH, Poole, Dorset, UK) for $10 \mathrm{~min}$ in a Beckman LS200 liquid scintillation counter. The efficiency of counting was $17.5 \%$ after quench corrections had been made by internal standardization with $\left[{ }^{14} \mathrm{C}\right]$ toluene and comparison to a quench curve constructed from ${ }^{14} \mathrm{C}$-quenched standards $(\mathrm{G} \& \mathrm{G}$ Chemical Services Ltd, Ascot, Berks, UK). The amount of radioactivity recovered per day was calculated.

Faeces. Radioactivity was extracted from faeces by first boiling with absolute ethanol ( $500 \mathrm{ml} / 250 \mathrm{~g}$ wet weight) for $10 \mathrm{~min}$. The vegetable matter was strained and the residue squeezed before re-extraction by boiling for $20 \mathrm{~min}$ with $750 \mathrm{ml}$ fresh absolute ethanol. Radioactivity in portions of $1,0.5$ and $0.25 \mathrm{ml}$ of each extract was counted. The extracts were combined and refluxed for $2 \mathrm{~h}$ at $70^{\circ} \mathrm{C}$, then concentrated on a Bucchi rotary evaporator (Rotavapor-R) and the residue reconstituted in ethanol $(200 \mathrm{ml})$. As approximately $83 \%$ of the total radioactivity recovered by extraction was present in the initial extract, with $17 \%$ in the second, it was concluded that the majority of extractable radiolabel had been extracted from the faeces and the residual vegetable matter was not analysed.

\section{Separation of conjugated and unconjugated steroids}

All subsequent analysis was carried out on the samples collected on Day 2 in which the majority of the injected radiolabel was recovered (see Table 1).

Urine. Unconjugated steroids were extracted from duplicate $50-\mathrm{ml}$ portions of urine with $300 \mathrm{ml}$ freshly distilled diethyl ether $(\mathrm{BDH})$ and the aqueous fraction (containing the conjugated steroids) was removed. The ether was evaporated to dryness and the residue redissolved in ethanol $(50 \mathrm{ml})$; radioactivity in duplicate 1 -ml portions was counted. Procedural losses were monitored in separate extractions by the addition of trace amounts of [ $\left.{ }^{3} \mathrm{H}\right]$ progesterone, in which recoveries of $82.9 \pm 4.6 \%$ (mean \pm s.e.m., $n=7$ ) were obtained. By repeating the procedure with $\left[{ }^{3} \mathrm{H}\right]$ oestrone sulphate (Amersham International) and $\left[{ }^{3} \mathrm{H}\right]$ pregnanediol glucuronide (Dr P. Samarajeewa, University College, London), it was demonstrated that $<3 \%$ of the conjugates were extracted by this procedure. 


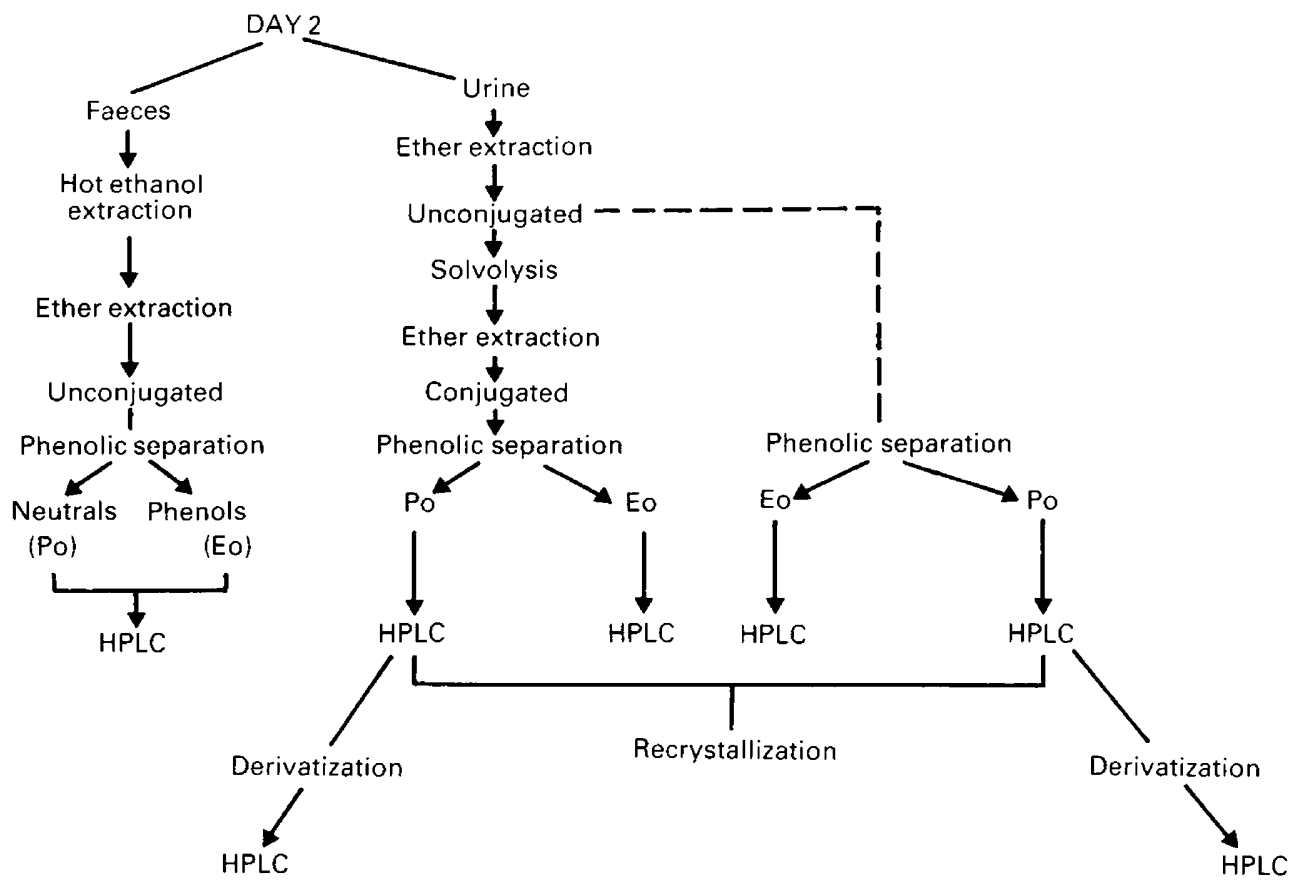

Fig. 1. Scheme for the separation and identification of oestrogen and progesterone metabolites in urine and faeces. The analysis was carried out on material collected the day after i.v. injection of $220 \times 10^{6}$ c.p.m. $\left[{ }^{14} \mathrm{C}\right]$ oestradiol- $17 \beta$ and $\left[{ }^{14} \mathrm{C}\right]$ progesterone.

Solvolysis (Hawkins \& Oakey, 1974), according to the method of Jacobsohn \& Lieberman (1962) as modified by Eastman et al. (1984), is a stringent procedure known to hydrolyse most steroid conjugates including glucuronides (Carroll et al., 1990) and was used to hydrolyse radiolabelled steroid conjugates in the urine. Volumes of the aqueous fraction $(50 \mathrm{ml})$, after ether extraction as above, were diluted to $100 \mathrm{ml}$ with phosphate-buffered saline, shaken with saturated sodium chloride solution $(50 \mathrm{ml}), 5 \mathrm{~N}$-sulphuric acid $(25 \mathrm{ml})$ and ethyl acetate $(200 \mathrm{ml})$ and incubated at $37^{\circ} \mathrm{C}$ for $24 \mathrm{~h}$. The solvent was removed and the aqueous phase re-extracted with $200 \mathrm{ml}$ fresh ethyl acetate. The organic phases were pooled, washed with water and evaporated to dryness. The residue was re-dissolved in absolute ethanol ( $50 \mathrm{ml})$, and radioactivity in $1-\mathrm{ml}$ portions of the solvent and the aqueous residue counted in duplicate. Residual radioactivity in the aqueous phase $(5 \cdot 2 \pm 2 \cdot 41 \%$ ) was not analysed but could possibly represent 17 -sulphated metabolites, unhydrolysed by solvolysis. The efficiency of the hydrolysis, monitored by repeating the procedure with phosphate buffer $(50 \mathrm{ml})$ containing trace amounts of $\left[{ }^{3} \mathrm{H}\right]$ pregnanediol glucuronide, was $91.9 \pm 3.7 \%(n=7)$. The hydrolysed conjugate fraction was retained.

Faeces. Ethanolic extracts of faeces were evaporated to dryness and the residue reconstituted in $10 \mathrm{ml}$ phosphatebuffered saline and extracted with $100 \mathrm{ml}$ freshly distilled diethyl ether. The ether was evaporated to dryness, the residue redissolved in $50 \mathrm{ml}$ ethanol and radioactivity in $1-\mathrm{ml}$ portions counted. Since $93 \%$ of the radioactivity recovered was present in the ether extract (associated with unconjugated steroids), further analysis was limited to this fraction.

\section{Separation of phenolic and neutral steroids}

Urine. Phenolic and neutral compounds in the hydrolysed conjugated and unconjugated fractions were separated by phenolic extraction according to a modification of the method of Brown (1955). Ethanolic extracts were dried and redissolved in $10 \mathrm{ml}$ petroleum ether (fraction $40-60^{\circ} \mathrm{C} ; \mathrm{BDH}$ ). Oestrogens were removed by extracting 3 times with $5 \mathrm{ml} 2 \mathrm{~N}$-sodium hydroxide solution, and the ether washed with water. Aqueous phases were combined and reextracted with fresh petroleum ether $(50 \mathrm{ml})$. Solvent extracts were combined to give the neutral fraction. The aqueous phase was adjusted to $\mathrm{pH} 7$ and extracted 3 times with freshly distilled diethyl ether $(75 \mathrm{ml})$ to form the phenolic fraction. Both fractions were evaporated to dryness and dissolved in absolute ethanol $(10 \mathrm{ml})$ before radioactivity was counted. Similar separations (coefficient of variation of $7.9 \%$ ) of phenolic and neutral compounds were obtained on 5 separate occasions. Ethanolic extracts were evaporated, the residue reconstituted in excess diethyl ether and dried over anhydrous sodium sulphate for $12 \mathrm{~h}$. 
Faeces. Ethanolic extracts were evaporated to dryness and the residue reconstituted in $10 \mathrm{ml}$ petroleum ether before phenolic extraction.

\section{Identification of steroids}

High-performance liquid chromatography (HPLC). Separations were obtained using a Lichrosorb silica 60 column $(250 \times 4 \mathrm{~mm}, 10 \mu \mathrm{m}$ particle size, MERK 50387). A linear gradient of $0-10 \%$ methanol in chloroform: $n$-hexane $(50$ : $50, \mathrm{v} / \mathrm{v}$ ) over $22 \mathrm{~min}$ at a flow rate of $2 \mathrm{ml} / \mathrm{min}$ was used to separate oestrogens (E. Möstl, personal comm.). Neutral steroids were separated using a linear gradient of $0-2 \%$ methanol in chloroform: $n$-hexane $(30: 70, \mathrm{v} / \mathrm{v})$ over $30 \mathrm{~min}$ at a flow rate of $2 \mathrm{ml} / \mathrm{min}$ (Carroll et al., 1990). All extracts were dried, reconstituted in the appropriate initial solvent for injection onto the column with ${ }^{3} \mathrm{H}$-steroids as standards. Fractions $(1 \mathrm{ml})$ were collected over $30 \mathrm{~min}$ and ${ }^{3} \mathrm{H}$ and ${ }^{14} \mathrm{C}$ radioactivity was counted in each on a tricarb liquid scintillation analyser (Packard, Pangbourne, Sussex, UK; $1900 \mathrm{CA})$. Using a spectrum analyser, calibrated in $\mathrm{keV}$, the region $0-18.6 \mathrm{keV}\left({ }^{3} \mathrm{H} \mathrm{E}_{\max }=18.6 \mathrm{keV}\right)$ was used to measure ${ }^{3} \mathrm{H}$ radioactivity and the region $0-156 \mathrm{keV}\left({ }^{14} \mathrm{C} \mathrm{E}_{\max }=156 \mathrm{keV}\right)$ was used to measure ${ }^{14} \mathrm{C}$ radioactivity. By considering the composite spectrum obtained, corrections were made for ${ }^{14} \mathrm{C}$ to ${ }^{3} \mathrm{H}$ crossover by the scintillation analyser which also provided a ${ }^{3} \mathrm{H} /{ }^{14} \mathrm{C}$ ratio value for each sample.

HPLC elution fractions containing ${ }^{14} \mathrm{C}$-labelled neutral steroids co-eluting with ${ }^{3} \mathrm{H}$-labelled standards were divided into two portions. Steroids in one portion underwent derivatization, whilst those in the other portion were recrystallized as described below. ${ }^{14} \mathrm{C}$-labelled oestrogens underwent recrystallization only.

Derivatization. Labelled neutral steroids in HPLC fractions identified by co-elution with ${ }^{3} \mathrm{H}$ standards were derivatized by selective reduction of the 3-oxo groups (Bush, 1961). Briefly, HPLC fractions were dried down and the radiolabelled steroids dissolved in $9 \mathrm{ml}$ methanol. A mixture of $2.5 \mathrm{M}$-sodium hydroxide $(0.1 \mathrm{ml})$, methanol (3 ml) and $0.18 \mathrm{M}$-sodium borohydride in pyridine $(2.8 \mathrm{ml})$ was added and the solution agitated with $\mathrm{N}_{2}$ for 10 min. After neutralization with hydrochloric acid, steroids were extracted with $200 \mathrm{ml}$ diethyl ether. The ether was washed with dilute sodium hydroxide, dried over sodium sulphate and evaporated to dryness.

Steroids were reconstituted in initial chromatography solvent and two samples analysed using the HPLC systems described previously. Fractions were collected and counted for ${ }^{3} \mathrm{H}$ and ${ }^{14} \mathrm{C}$ radioactivity.

Recrystallization. The identity of ${ }^{14} \mathrm{C}$-labelled steroid metabolites co-eluting with ${ }^{3} \mathrm{H}$-steroids on HPLC was determined by recrystallization to constant specific activity and ${ }^{3} \mathrm{H} /{ }^{14} \mathrm{C}$ ratio (Axelrod et al., 1965) after the addition of $25 \mathrm{mg}$ unlabelled carrier steroid. Steroids were dissolved in chloroform $(0.5 \mathrm{ml})$ and $0.05 \mathrm{ml}$ dispensed onto a preweighed planchette. Solvent was evaporated and the residue redissolved in warm acetone which was slowly evaporated whilst adding $n$-hexane in a drop-wise manner. The solution was transferred to $4^{\circ} \mathrm{C}$ and crystals grown for $24 \mathrm{~h}$. After a short centrifugation the supernatent was removed, crystals redissolved in $0.5 \mathrm{ml}$ chloroform and the process repeated. The mass of steroid and level of radioactivity in each planchette was determined, and the specific activity calculated. Recrystallization was not performed on the faecal steroids due to lack of sufficient radiolabel.

\section{Results}

\section{Distribution of radiolabelled steroids}

The amounts of urine and faeces excreted over the experimental period and the distribution of radioactivity are shown in Table 1 . Urinary and faecal excretion were low on Day 1, presumably whilst the animal recovered from the sedative. Of the administered label, $61 \%$ was recovered, $24.9 \%$ in urine and $35.6 \%$ in faeces; $90 \%$ of that excreted into the urine and $48 \%$ of that in faeces were recovered on Day 2.

On Day 2 similar proportions of radioactivity were associated with conjugated $(41 \cdot 2 \%)$ and unconjugated $(51.4 \%)$ steroids in the urine, whilst $92.4 \%$ was associated with unconjugated steroids in the faeces. After phenolic extraction, the urine was found to contain a larger proportion of neutral $(35 \%)$ than phenolic $(12 \%)$ unconjugated metabolites, whereas a similar amount of each ( $21 \%$ and $18 \%$ respectively) was found in the conjugated fraction. Overall, progesterone metabolites were predominant in the urine and oestrogen metabolites $(67 \%)$ were predominant in the faeces.

\section{Identification of radiolabelled steroids}

Urine. The HPLC elution profiles of neutral steroids in urine (Fig. 2) showed single peaks of ${ }^{14} \mathrm{C}$-label in both the conjugated and unconjugated fractions which co-eluted with $\left[{ }^{3} \mathrm{H}\right] 4$-pregnen- 
Table 1. Volume of urine and mass of faeces excreted on each day of the experiment, and the distribution of radioactivity in each sample shown as a percentage of total label administered

\begin{tabular}{|c|c|c|c|c|c|}
\hline & \multicolumn{2}{|c|}{ Urine } & \multicolumn{2}{|c|}{ Faeces } & \multirow{2}{*}{$\begin{array}{c}\text { Total } \\
\text { radioactivity } \\
\text { recovered } \\
(\%)\end{array}$} \\
\hline & $\begin{array}{l}\text { Volume } \\
\text { excreted (1) }\end{array}$ & $\%$ Total & $\begin{array}{c}\text { Mass } \\
\text { excreted (g) }\end{array}$ & $\%$ Total & \\
\hline Day 1 & 0.03 & - & - & - & - \\
\hline Day 2 & $20 \cdot 0$ & $23 \cdot 0$ & $26 \cdot 5$ & $17 \cdot 0$ & $40 \cdot 0$ \\
\hline Day 3 & 8.7 & 0.7 & $30 \cdot 9$ & $13 \cdot 1$ & $13 \cdot 8$ \\
\hline Day 4 & $21 \cdot 4$ & $1 \cdot 2$ & 47.7 & $5 \cdot 5$ & $6 \cdot 7$ \\
\hline \multicolumn{2}{|c|}{$\begin{array}{l}\text { Total radioactivity } \\
\text { recovered }(\%)\end{array}$} & 24.9 & & $35 \cdot 6$ & $60 \cdot 5$ \\
\hline
\end{tabular}

20a-ol-3-one and $\left[{ }^{3} \mathrm{H}\right]$ progesterone respectively. After derivatization, ${ }^{3} \mathrm{H}-$ and ${ }^{14} \mathrm{C}$-radioactivity continued to elute in similar proportions with the same retention time (Fig. 2). The identity of progesterone and 4-pregnen-20 $\alpha$-ol-3-one was subsequently confirmed when radiolabelled steroids were recrystallized to constant specific activity and ${ }^{3} \mathrm{H} /{ }^{14} \mathrm{C}$ ratio (Table 2 ). No radioactivity was seen to co-elute with pregnanediol in the conjugated or unconjugated fraction (Fig. 2).

The HPLC elution profile of phenolic steroids in the urine is shown in Fig. $3 .{ }^{14} \mathrm{C}$-Radioactivity was found to co-elute with $\left[{ }^{3} \mathrm{H}\right]$ oestrone in the conjugated and unconjugated fractions, and with $\left[{ }^{3} \mathrm{H}\right]$ oestradiol- $17 \beta$ in the unconjugated phenolic portion and $\left[{ }^{3} \mathrm{H}\right]$ oestradiol-17 $\alpha$ in the conjugated portion. The identity of these oestrogens was confirmed by recrystallization (Table 2).

Faeces. The only detectable peaks of ${ }^{14} \mathrm{C}$-radioactivity in faecal extracts co-eluted with $\left[{ }^{3} \mathrm{H}\right]-$ progesterone in the neutral fraction and with $\left[{ }^{3} \mathrm{H}\right]$ oestradiol-17 $\alpha$ and $\left[{ }^{3} \mathrm{H}\right]$ oestradiol-17 $\beta$ in the phenolic fraction on HPLC.

\section{Discussion}

The present study has established the identity of the major excretory products of exogenously administered oestradiol- $17 \beta$ and progesterone in a female southern white rhinoceros.

During the sample collection period a total of $61 \%$ of the injected label was recovered in excreted urine and faeces. Since radioactivity was still present in excreted material (especially faeces) collected at the end of the study (Day 4), a longer period of sample collection would have resulted in a higher overall recovery of label and a higher proportion of radioactivity present in faeces. Nevertheless, $39 \%$ of the radioactivity recovered was excreted in the urine indicating that, whilst faecal excretion may predominate, the urinary pathway was a significant route of excretion for gonadal steroid metabolites.

Radioactivity in faeces was associated exclusively with steroids in the unconjugated form. The possibility exists that 3-sulphoconjugated products present in faeces were hydrolysed during the ethanol extraction procedure, and were therefore not detected. Whilst biliary steroids can exist in the conjugated form (Støa \& Skulstad, 1972), it has been demonstrated from studies in the cow (Bamberg et al., 1986), sheep (Choi et al., 1987) and horse (Bamberg et al., 1984) that steroids are excreted into the faeces predominantly in the unconjugated form, probably after bacterial hydrolysis in the gut (Miyaziki et al., 1972).

Over $50 \%$ of the radioactivity in urine was unconjugated, in contrast to the findings of radiometabolism studies in other ungulates, e.g. the cow (Ivie et al., 1986) and pig (Schomberg et al., 1966), in which $<20 \%$ of excreted radiolabel was unconjugated. Furthermore, Kassam \& Lasley (1981) demonstrated, using sequential hydrolysis, that more than $95 \%$ of urinary oestrogens were present as conjugates in the Indian rhinoceros, with a comparable figure being reported for the black 


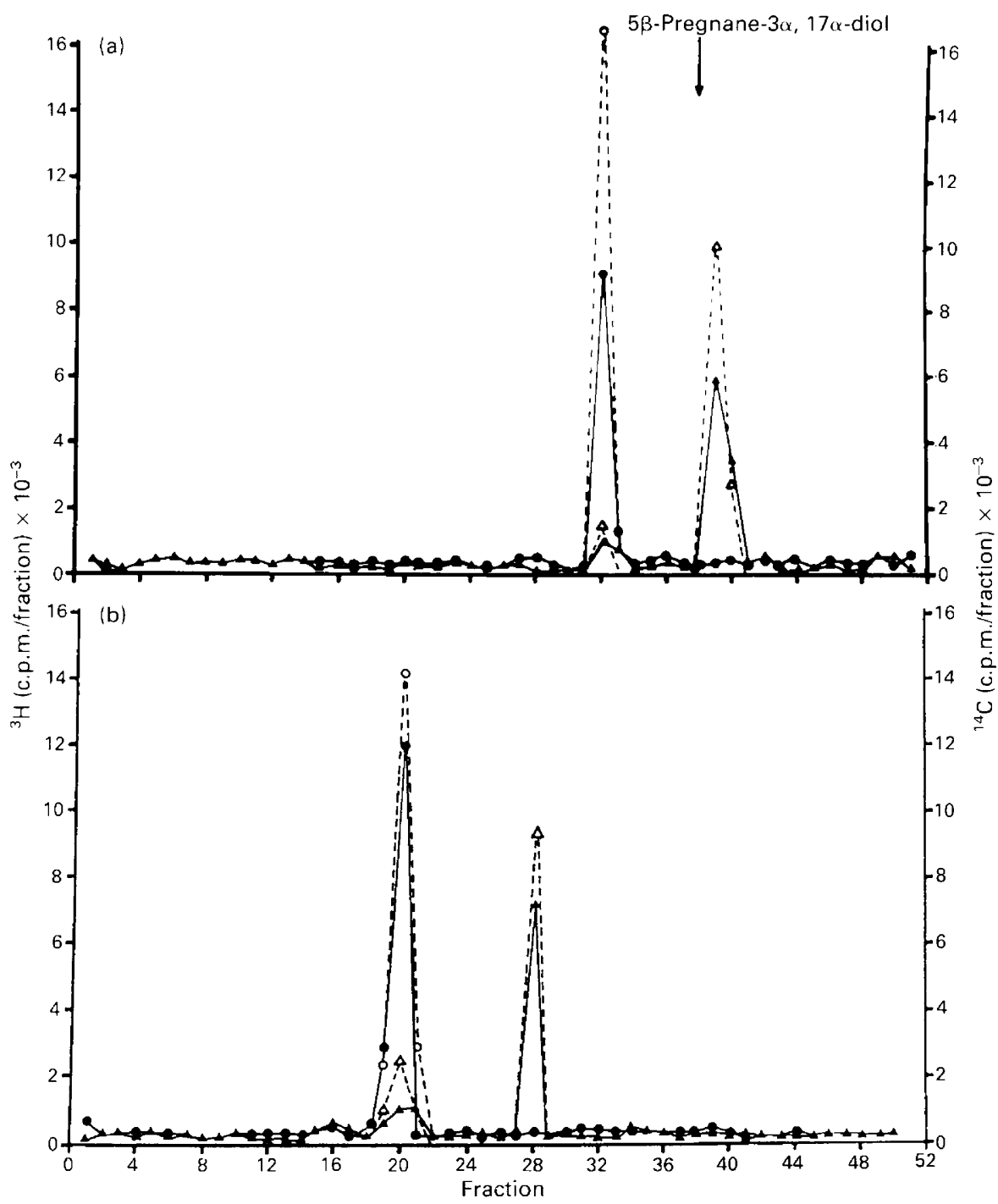

Fig. 2. HPLC elution profile of (a) conjugated and (b) unconjugated ${ }^{14} \mathrm{C}$-labelled neutral steroids (- $\longrightarrow$ in urine and added ${ }^{3} \mathrm{H}$-labelled 4-pregnen-20 $\alpha$-ol-3-one (a, --- ) or progesterone $(b,--)$. Elution profiles of steroids in the form in which they are excreted in (b) and after hydrolysis in (a); $\boldsymbol{\Delta}$, elution pattern of steroids after derivatization.

rhinoceros (Ramsay et al., 1987). There are several factors which may have influenced the concentration of unconjugated steroids in the urine. Firstly, it is possible that, in the present experiment, conjugated steroids were hydrolysed during storage at $-20^{\circ} \mathrm{C}$ despite the addition of a preservative. However, this process does not appear to have led to generation of unconjugated 4-pregnen-20 $\alpha$-ol-3-one in urine. It should also be noted that ${ }^{14} \mathrm{C}$-labelled oestradiol-17 $\beta$ may have been formed by the metabolism of injected progesterone. Furthermore, it is possible that the large dose of unlabelled steroids administered affected the pattern of metabolism.

In contrast to the small proportion of radioactivity associated with neutral steroids in the faeces, progestagens predominated in the urine, a distribution similar to that observed in other ungulates including the sheep (Stupnicki et al., 1969). The only urinary unconjugated neutral steroid was 
Table 2. Initial and final specific activities, ${ }^{3} \mathrm{H} /{ }^{14} \mathrm{C}$ ratio and the coefficients of variation during 5 successive recrystallizations of ${ }^{14} \mathrm{C}$-labelled steroids extracted from urine co-eluting with ${ }^{3} \mathrm{H}$-labelled steroids in HPLC and pure steroid

\begin{tabular}{|c|c|c|c|c|c|c|}
\hline \multirow[b]{2}{*}{$\begin{array}{l}\text { Co-eluting label } \\
\text { on HPLC }\end{array}$} & \multicolumn{3}{|c|}{$\begin{array}{l}\text { Specific activity } \\
\qquad(\mu \mathrm{Ci} / \mathrm{mg})\end{array}$} & \multicolumn{3}{|c|}{${ }^{3} \mathrm{H} /{ }^{14} \mathrm{C}$} \\
\hline & Initial & Final & $\begin{array}{l}\mathrm{CV} \\
(\%)\end{array}$ & Initial & Final & $\begin{array}{l}\text { CV } \\
(\%)\end{array}$ \\
\hline Unconjugated progesterone & $0 \cdot 36$ & $0 \cdot 34$ & $6 \cdot 5$ & $1 \cdot 15$ & $1 \cdot 14$ & $1 \cdot 2$ \\
\hline $\begin{array}{l}\text { 4-Pregnan-20a-ol-3-one } \\
\text { (hydrolysed conjugate) }\end{array}$ & $2 \cdot 33$ & $2 \cdot 11$ & $3 \cdot 9$ & $1 \cdot 80$ & $1 \cdot 71$ & $2 \cdot 1$ \\
\hline Unconjugated oestrone & $0 \cdot 97$ & $0 \cdot 89$ & $3 \cdot 2$ & 1.80 & 1.57 & $5 \cdot 0$ \\
\hline Unconjugated oestradiol-17 $\beta$ & $0 \cdot 65$ & $0 \cdot 50$ & $10 \cdot 1$ & $1 \cdot 57$ & $1 \cdot 48$ & $2 \cdot 1$ \\
\hline $\begin{array}{l}\text { Oestrone } \\
\text { (hydrolysed conjugate) }\end{array}$ & 0.51 & 0.46 & $7 \cdot 4$ & $2 \cdot 11$ & $2 \cdot 00$ & $2 \cdot 6$ \\
\hline $\begin{array}{l}\text { Oestradiol-17 } \beta \\
\text { (hydrolysed conjugate) }\end{array}$ & $1 \cdot 12$ & 0.89 & $9 \cdot 3$ & $2 \cdot 81$ & $2 \cdot 64$ & $2 \cdot 3$ \\
\hline
\end{tabular}

progesterone, whilst 4-pregnen-20a-ol-3-one accounted for more than $90 \%$ of the radiolabel in the conjugated fraction. Significantly, no conjugated pregnanediol was present in the urine. This finding is consistent with the observations of Ramsey et al. (1987) and Hindle et al. (1988) using HPLC and GC/MS analysis respectively of urine from non-pregnant black rhinoceroses, and is in marked contrast to observations made on the Indian species for which pregnanediol glucuronide is the major progesterone metabolite (Kasman et al., 1986; Hindle et al., 1988; Hodges \& Green, 1989). Although low levels of pregnanediol glucuronide immunoreactivity have been reported during the oestrous cycle of both the white and black rhinoceros (Hodges \& Hindle, 1988), they do no reflect ovarian function and, in view of the present findings, are most probably due to measurement of cross-reacting substances.

In addition to confirming the absence of pregnanediol glucuronide, the present results suggest conjugated 4-pregnen-20a-ol-3-one as the major urinary progesterone metabolite. Serum concentrations of 4-pregnen-20 $\alpha$-ol-3-one reflect corpus luteum function in the horse (van Rensburg \& van Niekerk, 1968; Seren et al., 1981) and non-specific measurement of urinary 4-pregnen-20 $\alpha$ ol-3-one has been used to monitor luteal function and pregnancy in various species, including the lion-tailed macaque (Shideler et al., 1985), killer whale (Walker et al., 1988) and giant panda (Monfort et al., 1989). No published data are available on the levels of urinary 4-pregnen-20a-ol-3-one in any ungulate, but its measurement should be informative in monitoring ovarian function in the white and possibly the black rhinoceros.

In contrast to the distribution of neutral steroids the amounts of radioactive phenolic steroids excreted into the urine and faeces were similar. Like other perissodactyls, including the tapir (Kasman et al., 1985), horse (Raeside \& Liptrap, 1975) and Indian rhinoceros (Kassam \& Lasley, 1981; Kasman et al., 1986), the white rhinoceros excretes conjugated oestrone as an abundant oestrogen metabolite in urine. The reason why measurement of urinary oestrone conjugates does not appear to reflect ovarian function in this species is unclear. The black rhinoceros excretes mainly oestrone glucuronide (Ramsay et al., 1987) although, as in the present study, the position and configuration of the conjugation is not known and certain single and/or double conjugated oestrogens may exist which would not have been detected by the antisera used previously.

Oestradiol-17 $\alpha$ was also an abundant conjugated metabolite of the injected oestradiol-17 $\beta$. Formation of a $17 \alpha$-epimer from $\left[{ }^{3} \mathrm{H}\right]$ oestradiol-17 $\beta$ has been demonstrated in the dog (Siegel et al., 1962), and measurement of oestradiol-17 $\alpha$ by immunoassay has been shown to reflect ovarian function accurately in the cow (Dobson \& Dean, 1974) and ruffed lemur (Shideler et al., 1983). 


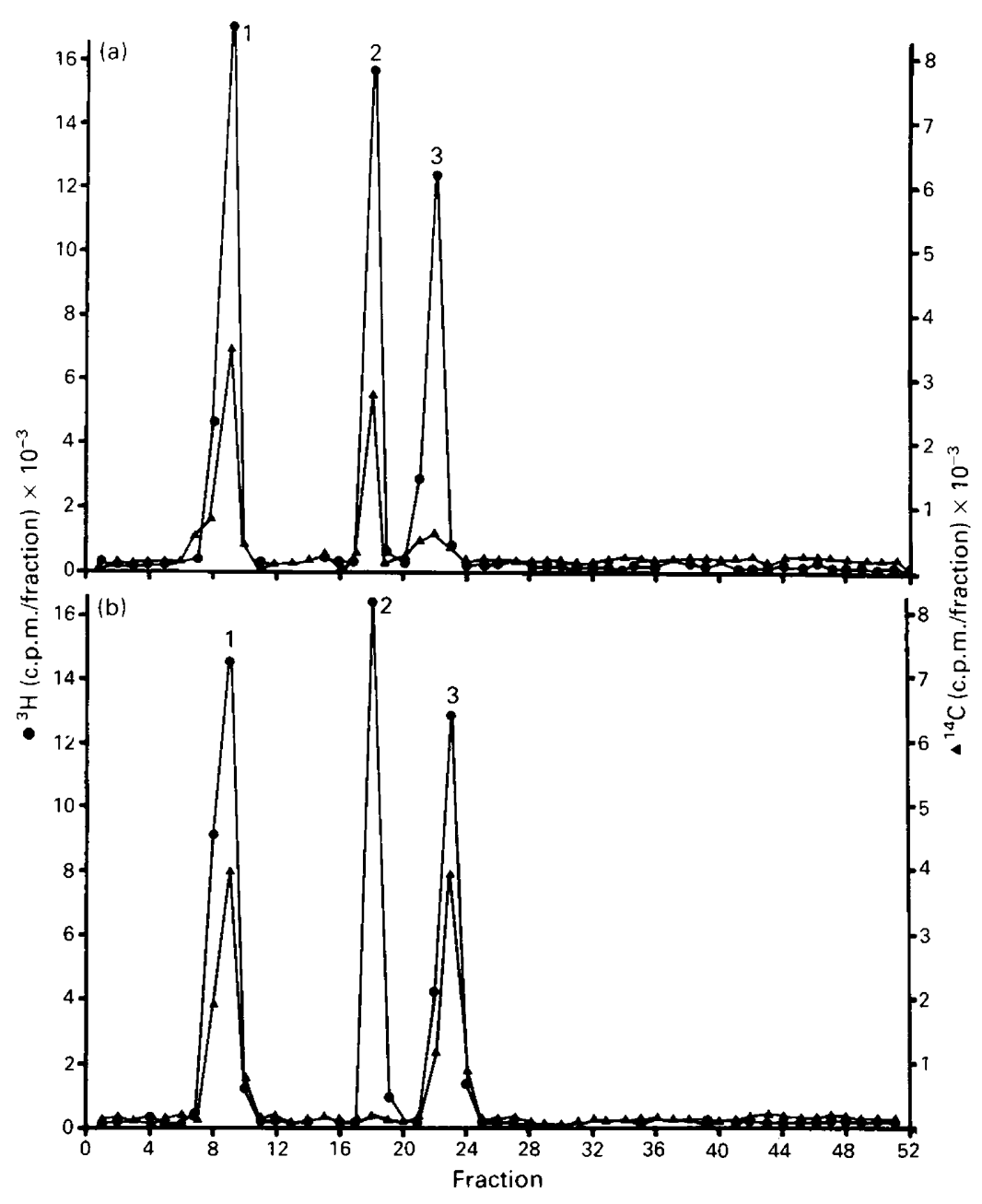

Fig. 3. HPLC elution profile of (a) unconjugated and (b) conjugated ${ }^{14} \mathrm{C}$-labelled phenolic steroids in urine and added ${ }^{3} \mathrm{H}$-labelled oestrone (1), oestradiol-17 $\alpha$ (2) and oestradiol-17 (3).

Urinary oestrone conjugates have not previously been shown to reflect ovarian function in the white rhinoceros, but measurement of oestradiol- $17 \alpha$ may be more informative.

Over $70 \%$ of radioactivity excreted into the faeces in this study was almost exclusively associated with oestrogenic steroids, and measurement of faecal oestrogens either collectively as total oestrogens (Möstl et al., 1987) or individually as oestradiol-17a (Möstl et al., 1984) may be useful in determining reproductive status. Such methods have been used for pregnancy diagnosis in a variety of species, including ungulates (Safar-Hermann et al., 1987), and may also be applicable to the detection of pregnancy in the white rhinoceros.

In conclusion, this study has shown that differences in steroid hormone metabolism and excretion exist between the African and Indian species of rhinoceros. Although the results obtained from this study require confirmation by analysis of urine collected during natural cycles, the identification of the major metabolites of injected oestradiol-17 $\beta$ and progesterone as described here should form the basis for the development of improved assay methods for monitoring ovarian function in the African rhinoceroses. Such methods are urgently needed to assist the captive management and breeding of these highly endangered species. 
We thank Dr W. F. Coulson and the staff of the Biochemistry Department, University College, London, Dr J. W. Honour of the Cobbold Laboratories, Middlesex Hospital, London, and Dr B. Chain of the Zoology Department, University College, London, for their constant advice and use of laboratory facilities during the early part of this study; Professor D. B. Gower, United Medical and Dental Schools, Guy's Hospital, London, for advice on steroid identification procedures; Dr E. Möstl, Institute of Biochemistry, Vienna, Austria, and Dr H. Stewart, AFRC Babraham, Cambridge, for the use of facilities and help with HPLC analysis; and Mr Vince Curzon and the keeper staff of the white rhinoceros section, Whipsnade, for their invaluable assistance with sample collection. Financial support was provided in part by Hoechst Animal Health, UK, and by a grant from the Nixon Griffis Fund for Zoological Research from the New York Zoological Society. J.E.H. was supported by a studentship from the Natural Environment Research Council and the Zuckerman Bursary from the Zoological Society of London.

\section{References}

Axelrod, L.R., Matthijssen, C., Goldzieher, J.W. \& Pulliam, J.E. (1965) Definitive identification of microquantities of radioactive steroids by recrystallization to constant specific activity. Acra endocr. Copenh., Suppl. 99, 7-66.

Bamberg, E., Choi, H.S., Möstl, E., Wurm, W., Lorin, D. \& Arbeiter, K. (1984) Enzymatic determination of unconjugated oestrogens in faeces for pregnancy diagnosis in mares. Equine vet. $J$. 16, 537-539.

Bamberg, E., Möstl, E., Wurm, W. \& Choi, H.S. (1986) Confirmation of pregnancy in mares and cattle by determination of estrogens in faeces. Proc. 10th Int. Congr. Anim. Reprod. \& A.I., Urbana 2, 75-80.

Brown, J.B. (1955) A chemical method for the determination of oestriol, oestrone and oestradiol in human urine. Biochem. J. 60, 185-193.

Bush, I.E. (1961) Microchemical reactions for steroids. In The Chromatography of Steroids, pp. 358-371. Pergamon Press, Oxford.

Carroll, J.B., Abbott, D.H., George, L.M., Hindle, J.E. \& Martin, R.D. (1990) Urinary endocrine monitoring of the ovarian cycle and pregnancy in Goeldi's monkey (Callimico goeldii). J. Reprod. Fert. 89, 149-161.

Choi, H.S., Kiesenhofer, E., Gantner, H., Hois, J. \& Bamberg, E. (1987) Pregnancy diagnosis in sows by estimation of oestrogens in blood, urine or faeces. Anim. Reprod. Sci. 15, 209-216.

Dobson, H. \& Dean, P.D.G. (1974) Radioimmunoassay of oestrone, oestradiol-17 $\alpha$ and oestradiol-17 $\beta$ in bovine plasma during the oestrous cycle and last stages of pregnancy. $J$. Endocr. 61, 479-486.

Eastman, S-A.K., Makawiti, D.W., Collins, W.P. \& Hodges, J.K. (1984) Pattern of excretion of urinary steroid metabolites during the ovarian cycle and pregnancy in the marmoset monkey. J. Endocr. 102, 19-26.

Hawkins, R.A. \& Oakey, R.E. (1974) Estimation of oestrone sulphate, oestradiol-17\% and oestrone in peripheral plasma: concentrations during the menstrual cycle and in men. J. Endocr. 60, 3-17.

Hindle, J.E., Coulson, W.F., Honour, J.W. \& Hodges, J.K. (1988) Comparative aspects of progesterone metabolism in the rhinoceros. J. Reprod. Fert., Abstr. Ser. 1, Abstr. 71.

Hodges, J.K. (1986) Monitoring changes in reproductive status. Int. Zoo $Y$ b. 24/25, 126-130.
Hodges, J.K. \& Green, D.I. (1989) A simplified enzyme immunoassay for urinary pregnanediol-3a-glucuronide: application to reproductive assessment in exotic species. J. Zool., Lond. 219, 89-100.

Hodges, J.K. \& Hindle, J.E. (1988) Comparative aspects of urinary hormone excretion in rhinoceroses: implications for reproductive assessment. In Proc. Sth Wld Conf. on Breeding Endangered Species in Captivity, pp. 83-91. Eds B. L. Dresser, R. W. Reece \& E. J. Maruska. Cincinnati Zoo, Ohio.

Ivie, G.W., Christopher, R.J., Munger, C.E. \& Coppock, C.E. (1986) Fate and residues of $\left[4-{ }^{14} \mathrm{C}\right]$ estradiol- $17 \beta$ after intramuscular injection into Holstein steer calves. J. Anim. Sci. 63, 681-690.

Jacobsohn, G. \& Lieberman, S. (1962) Studies on the chemical cleavage of the urinary glucuronosides of the 17-ketosteroids. J. biol. Chem. 237, 1469-1475.

Kasman, L.H., McCowan, B. \& Lasley, B.L. (1985) Pregnancy detection in tapirs by direct urinary estrone sulphate analysis. Zoo Biology 4, 301--306.

Kasman, L.H., Ramsay, E.C. \& Lasley, B.L. (1986) Urinary steroid evaluations to monitor ovarian function in exotic ungulates: III. Estrone sulphate and pregnanediol-3-glucuronide excretion in the Indian Rhinoceros (Rhinoceros unicornis). Zoo Biology 5, 355-361.

Kassam, A.A.H. \& Lasley, B.L. (1981) Estrogen excretory patterns in the Indian Rhinoceros (Rhinoceros unicornis), determined by simplified urinary analysis. Am. J. vet. Res. 42, 251-255.

Lasley, B.L. (1985) Methods of evaluating reproductive function in exotic species. Adv. vet. Sci. comp. Med. 30, 209-228.

Miyaziki, T., Peric-Golia, L., Slaunthwhite, W.R. \& Sandberg, A.A. (1972) Estriol metabolism in sheep: excretion of biliary and urinary conjugates. Endocrinology 90, 516-524.

Monfort, S.L., Dahl, K.D., Czekala, N.M., Stevens, L., Bush, M. \& Wildt, D.E. (1989) Monitoring ovarian function and pregnancy in the Giant panda (Ailuropoda melanoleuca) by evaluating urinary bioactive FSH and steroid metabolites. J. Reprod. Fert. 85, 203-212.

Möstl, E., Choi, H.S., Wurm, W., Ismail, N. \& Bamberg, E. (1984) Pregnancy diagnosis in cows and heifers by 
determination of oestradiol- $17 \alpha$ in faeces. Br. vet. J. 140, 287-291.

Möstl, E., Meyer, H.H.D., Bamberg, E. \& Von Hegel, G. (1987) Oestrogen determination in faeces of mares by enzyme immunoassay on microtitre plates. In Proc. Symp. on the Analysis of Steroids, pp. 219-224.

Raeside, J.I. \& Liptrap, R.M. (1975) Patterns of urinary oestrogen excretion in individual pregnant mares. $J$. Reprod. Fert., Suppl. 23, 469-475.

Ramsay, E.C., Kasman, L.H. \& Lasley, B.L. (1987) Urinary steroid evaluations to monitor ovarian function in exotic ungulates: $V$. Estrogen and pregnanediol3-glucuronide excretion in the Black Rhinoceros. Zoo Biology 6, 275-282.

Safar-Hermann, N., Ismail, M.N., Choi, H.S., Möstl, E. \& Bamberg, E. (1987) Pregnancy diagnosis in Zoo animals by estrogen determination in faeces. Zoo Biology 6, 189-193.

Schomberg, D.W., Jones, P.H., Featherston, W.R. \& Erb, R.E. (1966) Identification of metabolites of progesterone-4- ${ }^{14} \mathrm{C}$ in domestic sow urine. Steroids 8 , $277-282$.

Seren, E., Tamanini, C., Gaiani, R. \& Bono, G. (1981) Concentrations of progesterone, $17 \alpha$-hydroxyprogesterone and 20a-hydroxyprogesterone in the plasma of mares during pregnancy and at parturition. $J$. Reprod. Fert. 63, 443-448.

Shideler, S.E., Czekala, N.M., Benirschke, K. \& Lasley, B.L. (1983) Urinary estrogens during pregnancy of the ruffed lemur (Lemur variegatus). Biol. Reprod. 28, 963-969.
Shideler, S.E., Mitchell, W.R., Lindburg, D.G. \& Lasley, B.L. (1985) Monitoring luteal function in the liontailed macaque (Macaca silenus) through urinary progesterone metabolite measurements. Zoo Biology 4, 65-73.

Siegel, E.T., Dorfman, R.I., Brodey, R.S. \& Friedman, M.F.H. (1962) Conversion of $6,7-{ }^{3} \mathrm{H}$ estradiol- $17 \beta$ into estrone and estradiol-17 $\alpha$ in the mature male dog. Proc. Soc. exp. Biol. Med. 3, 533.

Stea, K.F. \& Skulstad, P.A. (1972) Biliary and urinary metabolites of intravenously and intraduodenally administered 17ß-oestradiol and oestriol. Steroids Lipids Res. 3, 299-314.

Stupnicki, R., McCracken, J.A. \& Williams, K.I.H. (1969) Progesterone metabolism in the ewe. $J$. Endocr. 45, 67-74.

van Rensburg, S.J. \& van Niekerk, C.H. (1968) Ovarian function, follicular oestradiol-17 $\beta$ and luteal progesterone and 20a-hydroxy-pregn-4-en-3-one in cycling and pregnant equines. Onderstepoort $J$. vet. Res. 35, 589-310.

Walker, L.A., Cornell, L., Dahl, K.D., Czekala, N.M., Dargen, C.M., Joseph, B., Hseuh, A.J.W. \& Lasley, B.L. (1988) Urinary concentrations of ovarian steroid hormone metabolites and bioactive follicle stimulating hormone in killer whales (Orcinus orchus) during ovarian cycles and pregnancy. Biol. Reprod. 39, 1013-1020.

Received 22 March 1990 